\title{
Article \\ Evaluating the Endophytic Activities of Beauveria bassiana on the Physiology, Growth, and Antioxidant Activities of Extracts of Lettuce (Lactuca sativa L.)
}

\author{
Neo Macuphe ${ }^{1}$ (D) Oluwafemi Omoniyi Oguntibeju ${ }^{2}(\mathbb{D})$ and Felix Nchu ${ }^{1, *(D)}$ \\ 1 Department of Horticultural Sciences, Cape Peninsula University of Technology, P.O. Box 1906, \\ Bellville 7535, South Africa; neomacuphe@gmail.com \\ 2 Phytomedicine and Phytochemistry Research Group, Oxidative Stress Research Centre, Department of \\ Biomedical Sciences, Faculty of Health and Wellness Sciences, Cape Peninsula University of Technology, \\ P.O. Box 1906, Bellville 7535, South Africa; oguntibejuo@cput.ac.za \\ * Correspondence: felixnchu@gmail.com
}

check for updates

Citation: Macuphe, N.; Oguntibeju, O.O.; Nchu, F. Evaluating the Endophytic Activities of Beauveria bassiana on the Physiology, Growth, and Antioxidant Activities of Extracts of Lettuce (Lactuca sativa L.). Plants 2021, 10, 1178. https://doi.org/10.3390/ plants10061178

Academic Editors: Oscar Santamaria and Sara Rodrigo

Received: 31 March 2021

Accepted: 5 May 2021

Published: 9 June 2021

Publisher's Note: MDPI stays neutral with regard to jurisdictional claims in published maps and institutional affiliations.

Copyright: (c) 2021 by the authors. Licensee MDPI, Basel, Switzerland. This article is an open access article distributed under the terms and conditions of the Creative Commons Attribution (CC BY) license (https:/ / creativecommons.org/licenses/by/ $4.0 /)$.

\begin{abstract}
Endophytic entomopathogens have growth promoting, nutrient fortifying, and anti-insect properties that could improve the yield and quality of lettuce (Lactuca sativa L.). Lactuca sativa is a vegetable crop with high demand; however, it is susceptible to aphid infestations. This study's objectives were to assess the pathogenicity of Beauveria bassiana (strain: SM3) (Bals.) Vuil. (Hypocreales) against Myzus persicae Sulzer, tissue colonization of lettuce by conidia of B. bassiana, as well as the effects of fungal inoculation on growth, tissue nutrient content, and proximate composition of the lettuce plants. Furthermore, the involvement of tissue nutrients in mediating the influence of endophytic fungus on the plant traits was examined. Insects and plants were exposed to four fungal conidial concentrations: $0,1 \times 10^{6}, 1 \times 10^{7}$ and $1 \times 10^{8}$ conidia $\mathrm{mL}^{-1}$ in an anti-insect bioassay and greenhouse experiment, respectively. The $B$. bassiana strain was pathogenic against $M$. persicae, inducing mean insect mortality of $78 \%$ at the highest concentration $\left(1 \times 10^{8}\right.$ conidia $\left.\mathrm{mL}^{-1}\right)$. The $\mathrm{B}$. bassiana endophytically colonized up to $76 \%$ of plants exposed to $1 \times 10^{8}$ conidia $\mathrm{mL}^{-1}$. Crown size and plant height varied significantly among treatments. However, the plant fresh and dry weights and nutrient elements $\mathrm{N}, \mathrm{P}, \mathrm{K}, \mathrm{Ca}$, and $\mathrm{Mg}$ did not vary significantly among treatments. Among the plant macronutrients assessed, only tissue carbon content was significantly $(p<0.01)$ affected by conidial treatments. The tissue $\mathrm{C}$ and $\mathrm{Cu}$ contents significantly correlated with the antioxidant capacity of the lettuce plants. Most of the micronutrients, viz. $\mathrm{Mn}, \mathrm{Fe}, \mathrm{Cu}$, and $\mathrm{B}$ were remarkably higher $(p<0.05)$ in the fungus-treated plants than in the control plants. The antioxidant capacity (FRAP and TEAC) of plant extracts varied significantly $(p<0.001)$ among treatments, with the highest conidial treatment yielding the most increased antioxidant activity. In conclusion, the B. bassiana strain was endophytic to lettuce, pathogenic against $M$. persicae, and induced increased micro-nutrient tissue contents and antioxidant activities. This study demonstrated that $B$. bassiana could be potentially used in the biofortification of nutritive and medicinal qualities of plants.
\end{abstract}

Keywords: Myzus persicae; Beauveria bassiana; Lactuca sativa; endophytic; colonization

\section{Introduction}

Lactuca (Asteraceae) is one of the most consumed salad vegetables in North America, South America, Europe, Australia, and New Zealand. Aphid infestations on this crop often lead to declines in lettuce yields and economic losses among commercial and small-scale farmers [1]. Aphids are sap-feeding insects that are capable of causing direct injury to plants and vectoring many damaging phytopathogens, including the lettuce mosaic virus [1]. Reducing aphid infestations is an efficient strategy to manage viruses and other vectorborne phytopathogens [2]. However, conventional aphid control still depends mostly on synthetic insecticides, which are often toxic to the environment $[3,4]$. Furthermore, 
prolonged, excessive, and widespread use of these chemicals have been associated with insect resistance to insecticide and reduced soil fertility [5]. Benign measures of aphid control need to be developed to achieve high quality and yield of lettuce.

Endophytic entomopathogenic fungi can colonize plant tissues without causing damage or disease to host plants [6]. They have been found in the tissues of different crops. Endophytic entomopathogenic fungi are vital in the agricultural and horticultural sectors because they provide protection against herbivorous insects through systemic resistance and are compatible with systemic insecticide application $[7,8]$. The use of fungal entomopathogens as endophytes in biological control has gained interest among researchers since 2010, resulting in a marked increase of published papers on the topic [9]. Endophytic fungi can enhance plant growth directly or indirectly [10] and improve plant adaptation to adverse conditions, including biotic and abiotic stresses [11-14].

Researchers are interested in the mechanisms through which endophytic fungi, including endophytic entomopathogenic fungi, protect plants and improve plant yield and nutritive value. For example, Beauveria bassiana (Bals.) Vuil. (Ascomycota: Hypocreales) can help plants adapt to different conditions, facilitate the transfer of nutrients from the soil to the roots, and regulate plant growth and defense [15-17]. Some endophytic fungi act as bio-stimulants that help disseminate macronutrients and micronutrients [18]. Nutrient translocation and uptake can enhance plant growth by modifying phytohormones $[14,19]$. Endophytic fungi and bacteria can produce or assist plants in producing secondary metabolites that can defend the plants against pathogens and pests $[17,20,21]$. White $\mathrm{Jr}$ and Torres [20] reported that plants colonized by endophytes produce more glucose and fructose. Some studies suggest that endophytic fungi stimulate antioxidants production in plants, which is essential for neutralizing reactive oxygen species [22]. Fungal endophytes can also solubilize phosphate [23] and produce phytohormones such as cytokinins, indole acetic acid (IAA), gibberellin (GAs), and siderophore. Some fungi supply essential vitamins to the plant host [12,24-28]. A study by Hamayun et al. [29] suggested that endophytic fungi enhanced proximate composition in plants. Endophytic entomopathogenic fungi have the potential to provide solutions to agricultural and medical problems [30].

One of the most studied entomopathogenic fungi is Beaveria bassiana (Bals.) Vuil. (Ascomycota: Hypocreales). Besides being a prolific insect pathogenic fungus, it is naturally endophytic in many crops [31]. Its endophytic trait is being exploited in the field of agriculture and medicine. Beauveria bassiana is a soil-borne cosmopolitan fungus, having a very wide range of hosts and is the basis for the production of many bioinsecticides against a wide range of insect pests [32]. Many isolates of B. bassiana have been used to artificially colonize tissues of food crops, including cucumber [31], tomatoes [33] and cabbage [34]. However, information on the endophytic activity of B. bassiana on lettuce is lacking; hence, the motivation for this study.

Although many studies have examined the effects of endophytic fungi on plant growth and secondary metabolites, few studies have simultaneously and comprehensively investigated the effects on tissue colonization, plant growth, nutrient contents, antioxidant capacity, and proximate components. Among these plant traits, tissue nutrient (mineral) content is central because it can significantly influence the other plant traits. For example, at tolerable ranges, higher levels of tissue macronutrients correlate with higher plant growth [35], higher chlorophyll contents [36] and lower secondary metabolites and antioxidant capacity [37,38].

A few studies have investigated the mechanisms through which nutrient elements mediate fungal endophytes' influences on plant traits. Recently, Chen et al. [39] demonstrated that increased concentration of many nutrient elements in leaves and roots is one of the possible mechanisms by which endophytic fungus Epichloë festucae var. lolii enhances survival of Lolium perenne in low fertility soil. Exposing L. sativa to Ca ions that were encapsulated in biopolymeric microparticles had a positive effect on secondary metabolites, antioxidant activity and chlorophylls [40]. Piriformospora indica stimulated both plant growth and P acquisition of trifoliate orange [41]. This study addresses two research questions. What 
are the effects of $B$. bassiana inoculation on the growth, physiology and the nutritive value of lettuce? Do tissue nutrients mediate B. bassiana's endophytic influence on the plant's traits? It is necessary to optimize the application of endophytic entomopathogenic fungi in biofortification, pest management and medicinal plant cultivation projects. More studies are needed to fully decipher how tissue minerals mediate the effects of endophytic fungi on plant functional traits, such as biomass, antioxidants, and proximate composition.

This study is intended to provide a deeper understanding of the effects of the endophytic entomopathogenic fungus B. bassiana (strain: SM3) on the physiology and nutritive value of L. sativa. The specific objectives of this paper were: (i) to assess the pathogenicity of $B$. bassiana against $M$. persicae in the laboratory, (ii) to assess colonization of lettuce by $B$. bassiana, (iii) to assess the effect of $B$. bassiana on growth, macronutrient and micronutrient contents, antioxidant contents, proximate components of L. sativa, chlorophyll content of lettuce, and (v) to explore the mediating role of tissue nutrient on the influence of endophytic B. bassiana on lettuce traits.

\section{Results}

\subsection{Pathogenicity Assessment}

Generally, the results showed that B. bassiana (strain: SM3) was pathogenic against M. persicae. Insect mortality increased with conidial concentration. The highest concentration $\left(1 \times 10^{8}\right.$ conidia $\left.\mathrm{mL}^{-1}\right)$ caused higher insect mortality $(78 \%)$ compared to other treatments $(\mathrm{DF}=3,20 ; \mathrm{F}=21.57 ; p<0.01)$ (Table 1$)$. The isolate had $\mathrm{LC}_{50}$ value of 1.1 to $1.6 \times 10^{6}$ conidia $\mathrm{mL}^{-1}$ (Table 1$)$.

Table 1. The pathogenicity (mean \pm SE number of dead insects and (Abbott-corrected percentage mortality), of Beauveria bassiana against Myzus persicae in the laboratory at five days post-treatment.

\begin{tabular}{cc}
\hline Treatments & $\begin{array}{c}\text { Mean } \pm \text { SE Number of Dead Insects and } \\
\text { (Abbott-Corrected Percentage Mortality) }\end{array}$ \\
\hline $\begin{array}{c}\text { Control } \\
1 \times 10^{6} \text { conidia } \mathrm{mL}^{-1}\end{array}$ & $0 \pm 0$ \\
$1 \times 10^{7}{\text { conidia } \mathrm{mL}^{-1}}^{-1}$ & $48 \pm 0.50$ \\
$1 \times 10^{8}{\text { conidia } \mathrm{mL}^{-1}}^{\text {LC }}$ & $66 \pm 0.31$ \\
\hline Fiducial limits (95\% CI) & $78 \pm 0.18$ \\
\hline
\end{tabular}

Means with the same lowercase letters in the column indicates means \pm SE are not significantly different using Tukey HSD test at $p=0.05$ level of significance.

\subsection{Colonization of Tissues by Fungus}

Beauveria bassiana was successfully re-isolated from the leaves of the plants at three weeks post-treatment. The number of plants colonized by the fungus increased significantly $\left(\mathrm{X}^{2}=34.05 ; \mathrm{DF}=3 ; p<0.001\right)$ with fungal concentration. The highest tissue colonization of $76 \%$ (Figure 1 and Figure S1) was obtained at $1 \times 10^{8}$ conidia $\mathrm{mL}^{-1}$ followed by treatments two $\left(1 \times 10^{7}\right)$ and one $\left(1 \times 10^{6}\right), 64 \%$ and $56 \%$. Similar results were obtained with the roots. The leaf and root sections from the control treatment had no fungal outgrowth.

\subsection{Effect of Fungus on Plant Height, Crown Size and Roots Length}

Generally, the $B$. bassiana inoculation significantly increased plant height (DF = 3, 196; $F=3.61 p<0.01$ ); the heights ranged from 15.52 to $16.04 \pm 0.18$ (Table 2). Similarly, there was a significant difference among the treatments in terms of crown size of the plant $(\mathrm{DF}=3,196 ; \mathrm{F}=14.52 ; p<0.001)$; generally, fungus-treated plants had larger crown sizes (Table 2). Unlike plant height and crown size, there was no significant difference in root lengths $(\mathrm{DF}=3,116 ; \mathrm{F}=0.996 ; p=0.40)$. 


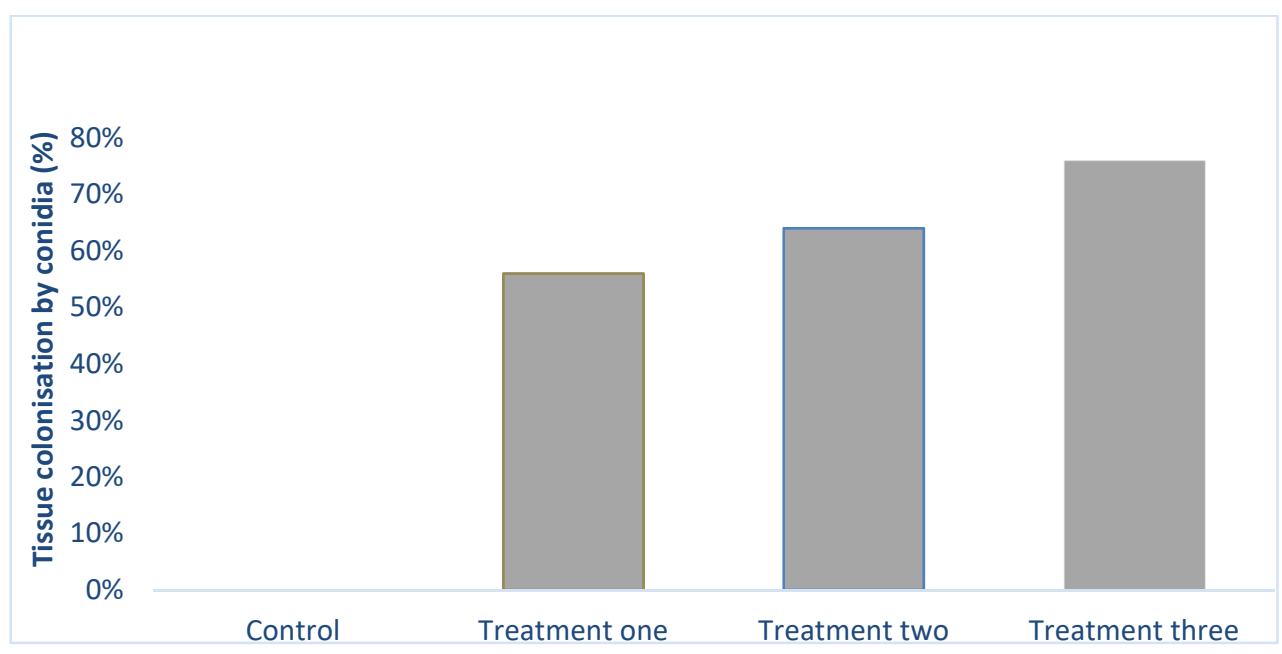

Figure 1. The fungal outgrowth on leaf section of L. sativa following B. bassiana inoculation at different conidia concentrations

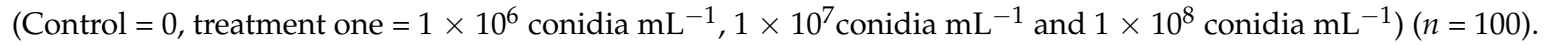

Table 2. The effect of Beauveria bassiana on root length, plant height and crown size of the plants (Lactuca sativa) at varying conidial concentrations $(n=200)$.

\begin{tabular}{|c|c|c|c|}
\hline Treatments & $\begin{array}{c}\text { Roots } \\
\text { Length }(\mathrm{cm})\end{array}$ & $\begin{array}{c}\text { Plant } \\
\text { Height }(\mathrm{cm})\end{array}$ & $\begin{array}{c}\text { Crown } \\
\text { Size }(\mathrm{cm})\end{array}$ \\
\hline Control & $19.50 \pm 0.54 \mathrm{a}$ & $15.52 \pm 0.10 \mathrm{a}$ & $25.94 \pm 0.19 \mathrm{a}$ \\
\hline $1 \times 10^{6}$ conidia $\mathrm{mL}^{-1}$ & $19.33 \pm 0.47 a$ & $16.02 \pm 0.12 b$ & $27.50 \pm 0.27 b c$ \\
\hline $1 \times 10^{7}$ conidia $\mathrm{mL}^{-1}$ & $20.10 \pm 0.51 \mathrm{a}$ & $16.02 \pm 0.12 b$ & $26.96 \pm 0.29 b$ \\
\hline $1 \times 10^{8}$ conidia $\mathrm{mL}^{-1}$ & $20.33 \pm 0.38 a$ & $16.04 \pm 0.18 \mathrm{~b}$ & $28.14 \pm 0.22 c$ \\
\hline
\end{tabular}

The same lowercase letters in the same column indicates means \pm SE are not significantly different using Tukey HSD test at $p=0.05$ level of significance.

Effect of Fungus on Fresh Weight and Dry Weight of the Root and Aerial Parts of Lettuce Plants

The fungus inoculation did not significantly affect (DF $=3,116 ; p>0.05)$ the fresh and dry weights of the root and aerial parts (Table 3).

Table 3. The effect of Beauveria bassiana on dry and fresh weights of aerial part and roots of plants (Lactuca sativa) exposed to different conidial concentrations $(n=120)$.

\begin{tabular}{ccccc}
\hline Treatments & $\begin{array}{c}\text { Roots Fresh } \\
\text { Weight (g) }\end{array}$ & $\begin{array}{c}\text { Plant Fresh } \\
\text { Weight (g) }\end{array}$ & $\begin{array}{c}\text { Roots Dry } \\
\text { Weight(g) }\end{array}$ & $\begin{array}{c}\text { Plant Dry } \\
\text { Weight (g) }\end{array}$ \\
\hline Control & $23.57 \pm 0.62 \mathrm{a}$ & $58.70 \pm 1.60 \mathrm{a}$ & $3.18 \pm 0.12 \mathrm{a}$ & $4.24 \pm 0.11 \mathrm{a}$ \\
$1 \times 10^{6}{\text { conidia } \mathrm{mL}^{-1}}^{-1}$ & $23.12 \pm 1.21 \mathrm{a}$ & $61.70 \pm 1.53 \mathrm{a}$ & $3.30 \pm 0.06 \mathrm{a}$ & $4.49 \pm 0.13 \mathrm{a}$ \\
$1 \times 10^{7}{\text { conidia } \mathrm{mL}^{-1}}^{-1}$ & $20.48 \pm 1.00 \mathrm{a}$ & $54.17 \pm 2.26 \mathrm{a}$ & $3.39 \pm 0.11 \mathrm{a}$ & $4.61 \pm 0.11 \mathrm{a}$ \\
$1 \times 10^{8}$ conidia $\mathrm{mL}^{-1}$ & $21.28 \pm 0.95 \mathrm{a}$ & $57.65 \pm 2.43 \mathrm{a}$ & $3.32 \pm 0.10 \mathrm{a}$ & $4.49 \pm 0.18 \mathrm{a}$ \\
\hline
\end{tabular}

The same lowercase letters in the same column indicates means \pm SE are not significantly different using Tukey HSD test at $p=0.05$ level of significance.

\subsection{Effect of Fungus (Beauveria bassiana) on Antioxidant Capacity: Ferric Reducing Antioxidant} Power (FRAP) and Trolox Equivalent Antioxidant Capacity (TEAC)

The treatment significantly influenced antioxidant capacity in plant extracts $(\mathrm{DF}=3$, $8 ; \mathrm{F}=6.067 p<0.001 \mathrm{FRAP}_{(\mu \mathrm{mol} \mathrm{AAE} / \mathrm{g})} ; \mathrm{DF}=3,8 ; \mathrm{F}=31.669 ; p<0.001 \mathrm{TEAC}(\mu \mathrm{mol} \mathrm{TE} / \mathrm{g})$, with higher levels occurring in the plants inoculated with the highest fungal conidial concentration $\left(1 \times 10^{8}\right.$ conidia $\left.\mathrm{mL}^{-1}\right)$ and in control treatments (Table 4) compared to the lower conidial concentrations of $1 \times 10^{6}$ conidia $\mathrm{mL}^{-1}$ and $1 \times 10^{7}$ conidia $\mathrm{mL}^{-1}$. The association between $C$ content and antioxidant capacity was significant; TEAC $\left(R^{2}=0.87\right.$; $y=1.379 x-462.93)$ and FRAP $\left(R^{2}=0.88 ; y=0.918 x-282.3\right)$ (Table S1). Among the tissue 
micronutrients, only tissue $\mathrm{Cu}$ level was strongly association with the antioxidant capacity; $\operatorname{FRAP}\left(\mathrm{R}^{2}=0.741 ; \mathrm{y}=-0.05 \mathrm{x}+8.11\right)$ and TEAC $\left(\mathrm{R}^{2}=0.75 ; \mathrm{y}=-0.036 \mathrm{x}+6.71\right)($ Table S1 $)$.

Table 4. The effect of Beauveria bassiana on the antioxidant capacity of lettuce extracts following exposure of plants (Lactuca sativa) to different conidial treatments during cultivation $(n=12)$.

\begin{tabular}{ccc}
\hline Treatments & $\begin{array}{c}\text { Frap }(\mu \text { mol AAE/g }) \\
\text { Mean } \pm \text { SE }\end{array}$ & $\begin{array}{c}\text { TEAC }(\mu \text { mol TE/g }) \\
\text { Mean } \pm \text { SE }\end{array}$ \\
\hline Control & $86.13 \pm 6.35 \mathrm{a}$ & $88.92 \pm 7.02 \mathrm{a}$ \\
$1 \times 10^{6}$ conidia $\mathrm{mL}^{-1}$ & $46.15 \pm 3.61 \mathrm{~b}$ & $32.17 \pm 6.43 \mathrm{~b}$ \\
$1 \times 10^{7}{\text { conidia } \mathrm{mL}^{-1}}_{1 \times 10^{8} \text { conidia } \mathrm{mL}^{-1}}^{55.81 \pm 13.15 \mathrm{~b}}$ & $43.14 \pm 4.40 \mathrm{~b}$ \\
\hline
\end{tabular}

The same lowercase letters in the same column indicates means \pm SE are not significantly different using Tukey HSD test at $p=0.05$ level of significance.

\subsection{Effect of Beauveria bassiana on Tissue Analysis}

\subsubsection{Macronutrients}

Among all the macronutrients, only carbon (C) tissue content was significantly ( $\mathrm{DF}=3$, $8 ; \mathrm{F}=34.67 ; p<0.01$ ) influenced by fungal treatment. Carbon varied significantly with fungal treatments; plants in the control and highest conidial concentration had relatively higher tissue carbon contents than the moderate conidial treatments $\left(1 \times 10^{6}{\text { conidia } \mathrm{mL}^{-1}}^{-1}\right.$ and $1 \times 10^{7}$ conidia $\mathrm{mL}^{-1}$ ). No significant differences in $\mathrm{N}, \mathrm{P}, \mathrm{K}, \mathrm{Ca}$, and $\mathrm{Mg}$ tissue contents were found among treatments (Table 5).

Table 5. Effects of inoculating lettuce plants (Lactuca sativa) with different conidial concentrations of Beauveria bassiana on tissue macronutrients contents $\left(\mathrm{g} \mathrm{kg}^{-1}\right)(n=12)$.

\begin{tabular}{|c|c|c|c|c|c|c|c|}
\hline Treatments & $\mathrm{C}$ & $\mathbf{N}$ & $\mathbf{P}$ & $\mathbf{K}$ & $\mathrm{Ca}$ & $\mathrm{Mg}$ & $\mathrm{Na}$ \\
\hline Control & $407.36 \pm 0.41 \mathrm{a}$ & $20.90 \pm 0.60 \mathrm{a}$ & $4.10 \pm 0.60 \mathrm{a}$ & $55.33 \pm 0.33 a$ & $10.10 \pm 0.45 a$ & $4.27 \pm 0.15 a$ & $2.43 \pm 0.14 a$ \\
\hline $1 \times 10^{6}$ conidia $\mathrm{mL}^{-1}$ & $365.50 \pm 3.36 b$ & $21.37 \pm 0.75 \mathrm{a}$ & $4.67 \pm 0.38 \mathrm{a}$ & $60.00 \pm 4.16 \mathrm{a}$ & $11.67 \pm 0.88 \mathrm{a}$ & $5.27 \pm 0.56 \mathrm{a}$ & $2.58 \pm 0.19 \mathrm{a}$ \\
\hline $1 \times 10^{7}$ conidia $\mathrm{mL}^{-1}$ & $363.13 \pm 1.48 b$ & $22.13 \pm 0.47 \mathrm{a}$ & $4.53 \pm 0.18 \mathrm{a}$ & $60.67 \pm 0.67 \mathrm{a}$ & $10.33 \pm 0.33 a$ & $5.20 \pm 0.23 a$ & $2.42 \pm 0.04 \mathrm{a}$ \\
\hline $1 \times 10^{8}$ conidia $\mathrm{mL}^{-1}$ & $396.33 \pm 6.55 \mathrm{a}$ & $21.20 \pm 0.81 \mathrm{a}$ & $4.60 \pm 0.30 \mathrm{a}$ & $58.33 \pm 2.73 a$ & $10.03 \pm 0.48 \mathrm{a}$ & $4.63 \pm 0.20 \mathrm{a}$ & $2.44 \pm 0.29 \mathrm{a}$ \\
\hline
\end{tabular}

The same lowercase letters in the same column indicates means \pm SE are not significantly different using Tukey HSD test at $p=0.05$ level of significance.

\subsubsection{Micronutrients}

Unlike the macronutrients, most micronutrients were significantly affected by conidial concentration in this study. Apart from $\mathrm{Zn}$, all the other tissue micronutrients $(\mathrm{Mn}, \mathrm{Fe}, \mathrm{B}$, $\mathrm{Cu}$ ) assessed varied significantly ( $\mathrm{DF}=3,8 ; p<0.05)$ among treatments, with a discernible association of fungal treatments and higher plant tissue micro-nutrient contents. The highest values for $\mathrm{Mn}(81.03 \pm 4.39), \mathrm{Cu}(5.90 \pm 0.26)$, and B (50.27 \pm 1.01$)$ were observed at $1 \times 10^{7}$ conidia $\mathrm{mL}^{-1}$ (Table 6). The tissue Fe (iron) content was highest at the highest conidial treatment, lowest in the control treatment, and the differences among treatments were statistically significant $(\mathrm{DF}=3,8 ; \mathrm{F}=7.956 ; p<0.01$ ).

Table 6. Effects of inoculating lettuce plants (Lactuca sativa) with different conidial concentrations of Beauveria bassiana on tissue micronutrients contents $\left(\mathrm{mg} \mathrm{kg}^{-1}\right)(n=12)$.

\begin{tabular}{cccccc}
\hline Treatments & Mn & Fe & Cu & Zn & B \\
\hline Control & $54.73 \pm 5.25 \mathrm{a}$ & $286.00 \pm 17.47 \mathrm{a}$ & $2.87 \pm 0.33 \mathrm{a}$ & $47.27 \pm 7.13 \mathrm{a}$ & $38.70 \pm 1.29 \mathrm{a}$ \\
$1 \times 10^{6}$ conidia $\mathrm{mL}^{-1}$ & $70.63 \pm 7.58 \mathrm{ab}$ & $439.33 \pm 41.91 \mathrm{~b}$ & $5.00 \pm 0.15 \mathrm{~b}$ & $39.77 \pm 3.48 \mathrm{a}$ & $45.43 \pm 2.57 \mathrm{ab}$ \\
$1 \times 10^{7}{\text { conidia } \mathrm{mL}^{-1}}^{-1}$ & $81.03 \pm 4.39 \mathrm{~b}$ & $427.33 \pm 2.85 \mathrm{~b}$ & $5.90 \pm 0.26 \mathrm{~b}$ & $38.33 \pm 4.99 \mathrm{a}$ & $50.27 \pm 1.01 \mathrm{~b}$ \\
$1 \times 10^{8}$ conidia $\mathrm{mL}^{-1}$ & $72.60 \pm 1.99 \mathrm{ab}$ & $464.67 \pm 34.36 \mathrm{~b}$ & $3.57 \pm 0.35 \mathrm{a}$ & $36.10 \pm 2.21 \mathrm{a}$ & $46.27 \pm 3.44 \mathrm{ab}$ \\
\hline
\end{tabular}

The means \pm SE followed by the same lowercase letters column indicates means \pm SE are not significantly different using Tukey HSD test at $p=0.05$ level of significance. 


\subsection{Proximate Results}

\subsubsection{Protein}

Generally, there was a significant difference in protein contents among treatments $(\mathrm{DF}=3,8 ; \mathrm{F}=5.18 ; p<0.05)$. Plants in the treatment $1 \times 10^{6}$ conidia $\mathrm{mL}^{-1}$ had the lowest protein content compared with the other treatments (Table 7).

Table 7. Effects of inoculating lettuce plants with different conidial concentrations of Beauveria bassiana on protein contents $\left(\mathrm{g} \mathrm{kg}^{-1}\right)(n=12)$.

\begin{tabular}{cc}
\hline Treatments & $\begin{array}{c}\text { Protein }\left(\mathbf{g ~ k g}^{-\mathbf{1}}\right) \\
\text { Mean } \pm \text { SE }\end{array}$ \\
\hline Control & $27.87 \pm 2.02 \mathrm{ab}$ \\
$1 \times 10^{6}$ conidia $\mathrm{mL}^{-1}$ & $23.20 \pm 1.19 \mathrm{a}$ \\
$1 \times 10^{7}$ conidia $\mathrm{mL}^{-1}$ & $32.01 \pm 2.25 \mathrm{ab}$ \\
$1 \times 10^{8}$ conidia $\mathrm{mL}^{-1}$ & $34.06 \pm 2.26 \mathrm{~b}$ \\
\hline
\end{tabular}

The same lowercase letter in the same column indicates means \pm SE are not significantly different using Tukey HSD test at $p=0.05$ level of significance.

\subsubsection{Fatty Acids}

Fungal inoculation had no influence on palmitic acid ( $\mathrm{DF}=3,8 ; \mathrm{F}=0.66 p>0.05)$, linoleic acid ( $\mathrm{DF}=3,8 ; \mathrm{F}=4.00 ; p>0.05)$, linolenic acid ( $\mathrm{DF}=3,8 ; \mathrm{F}=3.14 ; p>0.05)$ and total fatty acids $(\mathrm{DF}=3,8 ; \mathrm{F}=1.17 ; p>0.05)$. However, the total fatty acids were relatively higher in the control plants $(1566.67 \pm 233.33)$ than in those of fungal treatments (Table 8).

Table 8. Influence of Beauveria bassiana on proximate composition of Lactuca sativa $\left(\mathrm{mg} \mathrm{kg}^{-1}\right)(n=12)$.

\begin{tabular}{|c|c|c|c|c|}
\hline Treatments & $\begin{array}{l}\text { Palmitic Acid } \\
\text { Mean } \pm \text { SE }\end{array}$ & $\begin{array}{c}\text { Linoleic Acid } \\
\text { Mean } \pm \text { SE }\end{array}$ & $\begin{array}{c}\text { Linolenic Acid } \\
\text { Mean } \pm \text { SE }\end{array}$ & $\begin{array}{c}\text { Total Fatty Acids } \\
\text { Mean } \pm \text { SE }\end{array}$ \\
\hline Control & $366.67 \pm 33.33 \mathrm{a}$ & $266.67 \pm 33.33 \mathrm{a}$ & $933.33 \pm 166.67 \mathrm{a}$ & $1566.67 \pm 233.33 \mathrm{a}$ \\
\hline $1 \times 10^{6}$ conidia $\mathrm{mL}^{-1}$ & $466.67 \pm 166.67 \mathrm{a}$ & $200.00 \pm 0.00 \mathrm{a}$ & $566.67 \pm 33.33 \mathrm{a}$ & $1233.33 \pm 185.59 \mathrm{a}$ \\
\hline $1 \times 10^{7}$ conidia $\mathrm{mL}^{-1}$ & $300.00 \pm 0.00 \mathrm{a}$ & $200.00 \pm 0.00 \mathrm{a}$ & $733.33 \pm 33.33 \mathrm{a}$ & $1233.00 \pm 33.33 \mathrm{a}$ \\
\hline $1 \times 10^{8}$ conidia $\mathrm{mL}^{-1}$ & $400.00 \pm 0.00 \mathrm{a}$ & $200.00 \pm 0.00 \mathrm{a}$ & $833.33 \pm 33.33 \mathrm{a}$ & $1433.33 \pm 33.33 \mathrm{a}$ \\
\hline
\end{tabular}

The same lowercase letter in the same column indicates means \pm SE are not significantly different using Tukey HSD test at $p=0.05$ level of significance. ND denotes not detected.

\subsection{Chlorophyll}

Generally, the exposure to $B$. bassiana conidia did not statistically affect chlorophyll contents $\left(\mathrm{DF}=3,8 ; \mathrm{F}=2.45 ; p>0.05 ;\right.$ total chlorophyll $\left.\mu \mathrm{g} \mathrm{g} \mathrm{g}^{-1}\right),(\mathrm{DF}=3,8 ; \mathrm{F}=2.26 ; p=0.05$;

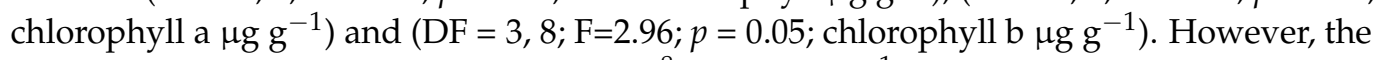
chlorophyll contents were higher at $1 \times 10^{8}$ conidia $\mathrm{mL}^{-1}$ (Table 9).

Table 9. Effects of inoculating lettuce plants with different conidial concentrations of Beauveria bassiana on total chlorophyll and chlorophyll contents a and $\mathrm{b}$ (Mean $\left.\pm \mathrm{SE} \mu \mathrm{g} \mathrm{g}^{-1}\right)(n=12)$.

\begin{tabular}{cccc}
\hline Treatments & Total Chlorophyll & Chlorophyll a & Chlorophyll b \\
\hline Control & $503.13 \pm 36.73 \mathrm{a}$ & $368.51 \pm 28.31 \mathrm{a}$ & $134.75 \pm 8.45 \mathrm{a}$ \\
$1 \times 10^{6}{\text { conidia } \mathrm{mL}^{-1}}_{1 \times 10^{7} \text { conidia } \mathrm{mL}^{-1}}^{488.93 \pm 6.71 \mathrm{a}}$ & $520.84 \pm 25.97 \mathrm{a}$ & $381.12 \pm 17.15 \mathrm{a}$ & $133.89 \pm 1.56 \mathrm{a}$ \\
$1 \times 10^{8}$ conidia $\mathrm{mL}^{-1}$ & $586.51 \pm 31.21 \mathrm{a}$ & $425.39 \pm 22.37 \mathrm{a}$ & $139.85 \pm 8.38 \mathrm{a}$ \\
\end{tabular}

Means with the same lowercase letters in the same column are not significantly different following comparison using the Tukey HSD at $p=0.05$ level of significance.

\section{Discussion}

The B. bassiana strain used in this study was pathogenic against female aphids and colonized lettuce plants in the laboratory and greenhouse experiments, respectively. Despite the evidence of successful tissue colonization by the fungus, minimal effects were observed 
on tissue macronutrient contents. However, conidial inoculation significantly $(p<0.05)$ enhanced tissue micronutrient, carbon tissue, and antioxidant contents. Fungal inoculation had varied effects on the different growth parameters.

The $B$. bassiana used in this study induced aphid mean mortalities ranging from $48-78 \%$ insects in the in vitro bioassay, increasing significantly $(p<0.001)$ with concentrations and demonstrating that this fungus is pathogenic against aphids [42-44]. Beauveria bassiana species has been known to be particularly virulent against sap-sucking homopterans. It can secrete mycotoxins, including proteases and chitinases, which degrade insect cuticles [45].

This study demonstrated that, depending on the concentration, the B. bassiana (strain: SM3) colonized $56 \%$ to $76 \%$ of lettuce's leaf tissue at six weeks post-treatment. The fungal colonization observed in this study could be described as moderate to high. The colonization of plant tissues by a fungus can be influenced by several factors, including the concentration of fungal conidia, age of the plant [46], and type of fungal strain selected $[47,48]$. Moreover, some inoculation methods enhance colonization of plant tissues by endophytic entomopathogenic fungi [49]. For example, seed inoculation produced higher colonization than seedling inoculation in onion plants [49].

The effects of $B$. bassiana isolate used in this study varied according to the plant growth parameter. Plant height and crown size of the plants were significantly affected $(p<0.05)$ by fungal inoculation, while fresh and dry weights were not significantly affected $(p>0.05)$ despite fungal colonization of the lettuce. Nevertheless, it is widely believed that fungal endophytes promote plant growth [50,51]. Previously, Dash et al. [52] reported that entomopathogenic fungi such as B. bassiana, Isaria fumosorosea and Lecanicillium lecanii enhanced the growth of bean plants. However, the effect of endophytic fungi on plant growth parameters can vary with host and isolates [48]. The mechanisms through which the endophytic fungi influence the different growth parameters need to be better understood. Endophytic fungi produce siderophores and organic acids, altering the bioavailability of a variety of nutrients [52].

Despite the successful colonization of plant tissues, there was no statistical difference in tissue macronutrients for most macronutrients measured, i.e., $\mathrm{N}, \mathrm{P}, \mathrm{K}, \mathrm{Ca}$, and $\mathrm{Mg}$. Because $\mathrm{N}, \mathrm{P}, \mathrm{K}, \mathrm{Ca}$, and $\mathrm{Mg}$ are important for increased plant growth and biomass accumulation and were not affected by B. bassiana inoculation in this study, it is, therefore, not surprising the results in the current study showed that the fungus had little effect on plant fresh and dry weights. Similarly, the fungus did not influence the chlorophyll content. N, Ca, K, and $\mathrm{Mg}$ are key nutrients that are responsible for the synthesis of chlorophyll. Previously, Rozpadek et al. [53] demonstrated that endophytic fungus improves chlorophyll content in plants. However, the fungus affected $C$ tissue content; it was higher in the control plants and the highest concentration of $1 \times 10^{8}$ conidial $\mathrm{mL}^{-1}$ compared with plants in the other treatments $\left(1 \times 10^{6}\right.$ and $\left.1 \times 10^{7}\right)$ (Table 5). The high carbon content might be linked to higher amounts of structural carbon or carbon-based compounds [54] or increased carbohydrate accumulation due to increased photosynthesis [55,56]. Moreover, some microbes have high-affinity transporters that enable them to detect and absorb organic carbon nutrients and minerals in the form of organic acid-metal complexes from a growth medium or soil [57]. However, the reason for the lower tissue carbon in treatments $1 \times 10^{6}$ and $1 \times 10^{7}$ conidia $\mathrm{mL}^{-1}$ in this study is not clear. It is necessary to carry out further studies to understand the relationship between endophytic fungi and carbon content in plants.

The trend of the tissue micronutrient contents was quite obvious and interesting, as shown in the current results. There were statistical differences $(p<0.05)$ between fungal treated and control plants in four of the five micronutrients assessed, with control plants having consistently lower levels of $\mathrm{Mn}, \mathrm{Fe}, \mathrm{Cu}$, and $\mathrm{B}$ than fungus-inoculated plants. Endophytic fungi can synthesize some of these micronutrients and improve the uptake of these nutrients [58]. While these elements are needed in small quantities, they have important physiological roles in plants: Fe is needed for the biosynthesis of chlorophyll in plants [59]; B is an essential microelement in the metabolism of nucleic acid, carbohydrates and protein [60]; Cu plays critical roles in the physiological processes of plant such 
as photosynthesis, respiration, carbohydrate distribution, nitrogen fixation, metabolism of protein and antioxidant activity [61] and Mn is significant for metabolism and plant development [62]. The deficiency or excess of these micronutrients can be detrimental to plants $[63,64]$. For example, Fe deficiency can cause yellowing and chlorosis on new leaves and reduces sugar metabolic enzymes [65]. Furthermore, the production of secondary metabolites is influenced by the concentration of micronutrients in plants, and these micronutrients are needed in small amounts $[63,64]$. In this study, we observed that plants that were exposed to the highest concentration of fungal suspensions yielded the highest Fe content and antioxidant capacity. On further examination, we found weak correlation between Fe content and antioxidant capacity, TEAC $\left(R^{2}=0.0966 ; y=0.1275 x+116.94\right)$ and FRAP $\left(R^{2}=0.01 ; y=0.0975 x+108.69\right)$ despite Fe being a powerful reducing agent $([66,67]$. Nevertheless, $\mathrm{Cu}$ content significantly correlated with antioxidant capacity, FRAP $\left(R^{2}=0.741 ; y=-0.05 x+8.11\right)$ and TEAC $\left(R^{2}=0.75 ; y=-0.036 x+6.71\right)$ (Table S1).

Another interesting observation was the strong correlation between $C$ content and antioxidant capacity; TEAC $\left(\mathrm{R}^{2}=0.87 ; \mathrm{y}=1.379 \mathrm{x}-462.93\right)$ and FRAP $\left(\mathrm{R}^{2}=0.88\right.$; $y=0.918 x-282.3)$ assays. It is worth noting that carbon-based secondary metabolites have antioxidant properties [68], and some endophytic fungal strains are a source of antioxidants [69]. Proximate and phytochemical analyses may help clarify the nature of the carbon in the plant tissue. Future studies on metabolomics may also help explain the relationship between the carbon contents and the antioxidant capacity.

Endophytic fungi are capable of enhancing or producing biochemical metabolites that can be exploited in agriculture [70,71]. Based on the proximate analysis protein was significantly different $(p<0.05)$. This is interesting because the tissue nitrogen content, which often correlates with protein content, was not significantly $(p>0.05)$ affected by B. bassiana inoculation. Further investigations are needed to determine the protein types and sources. Proteins play an important role in the growth and nutritive value of plants and can mediate the production of antioxidants [72]. The fatty acids' contents did not vary significantly $(p>0.05)$ among conidial concentrations.

\section{Materials and Methods}

\subsection{Research Design}

Laboratory and greenhouse experiments were carried out in this study. The selected Beauveria bassiana (SM3) was evaluated using an insect mortality bioassay to determine if it was pathogenic Myzus persicae and could be considered for further study-the greenhouse study. In the greenhouse study, potted lettuce plants were allocated to one of four treatment groups in a complete randomized design, with a single factor. Plants in each treatment group were exposed to one of four fungal conidial concentrations: $0,1 \times 10^{6}, 1 \times 10^{7}$, and $1 \times 10^{8}$ conidia $\mathrm{mL}^{-1}$. The effects of fungal inoculation on plant growth, plant physiology, plant secondary metabolites, and insect infestations were assessed. All experimental plants were maintained under the same environmental conditions.

\subsection{Plants Material}

Lettuce (L. sativa) seedlings (cultivar: Green Oak) were sourced from Stodels Nurseries (Pty) Ltd in Bellville, Western Cape Province, South Africa. They were kept in the greenhouse of the Cape Peninsula University of Technology (CPUT), Bellville, South Africa, under the following conditions: $25 \pm 2{ }^{\circ} \mathrm{C}, 60-80 \% \mathrm{RH}$, and 14/10 natural light/dark regime. Each plant was gently removed from the six-pack tray of lettuce seedlings and transplanted into a $15 \mathrm{~cm}$ diameter pot containing a substrate mix: one-part silica sand, one-part perlite, and one-part peat moss. Before its use, the substrate mix was sterilized with $1 \%$ sodium hypochlorite for $30 \mathrm{~min}$ and was rinsed with sterile distilled water three times. Plants were fed using recommended hydroponics Nutrifeed ${ }^{\circledR}$ hydroponic fertilizer (Starke Ayres Pty. Ltd., Cape Town, South Africa). The fertilizer was mixed with sterile distilled water at a concentration of $10 \mathrm{~g} / 5000 \mathrm{~mL}$, and each potted plant was drenched 
with $200 \mathrm{~mL}$ once a week. Subsequently, each plant was watered with distilled water once a week for six weeks.

\subsection{Fungus Preparation}

An existing B. bassiana (SM3) strain that was previously isolated from a vineyard and identified molecularly by Moloinyane and Nchu [48] was used in this study. The fungus was cultured on a selective medium: half-strength $(19.5 \mathrm{~g} / 1000 \mathrm{~mL})$ of Potato Dextrose Agar (PDA) (Sigma-Aldrich PTY. LTD., Johannesburg, South Africa), 0.04 g streptomycin, and $0.02 \mathrm{~g}$ ampicillin sodium salt. The PDA was prepared in $9 \mathrm{~cm}$ - and $14 \mathrm{~cm}$-diameter Petri dishes. Fungal cultures were incubated for three weeks at $25 \pm 2{ }^{\circ} \mathrm{C}$ in the darkness. The mature conidia of $B$. bassiana were harvested using a sterile spatula and transferred into a $50 \mathrm{~mL}$ centrifuge tube containing $30 \mathrm{~mL}$ sterile water. The tube was capped and shaken for $3 \mathrm{~min}$ and mixed vigorously for two minutes using a vortex mixer (MI0101002D Vortex Mixer, Silverson Machines, Inc., East Longmeadow, MA, USA) at $3000 \mathrm{rpm}$ to homogenize the conidial suspension. The homogenous conidial suspension was transferred into $1000 \mathrm{~mL}$ bottles containing $500 \mathrm{~mL}$ sterile distilled water and $0.05 \%$ Tween 80 (Polysorbate, Sigma-Aldrich, Johannesburg, South Africa). The conidia concentration was determined using a haemocytometer (Bright-Line, Sigma-Aldrich, Johannesburg, South Africa) and observed with a light microscope at $400 \times$ magnification to determine the required concentration of $\left(1 \times 10^{8}, 1 \times 10^{7}\right.$, and $1 \times 10^{6}$ conidia $\left.\mathrm{mL}^{-1}\right)$. Germination percentage was assessed on 100 spore count at $40 \times$ magnification [73]. Each plate was replicated four times, and over $90 \%$ germination was observed.

\subsection{Pathogenicity Against Myzus Persicae}

The pathogenicity of B. bassiana strain (SM3) on Myzus persicae was tested against the three different conidial suspensions of endophytic fungus B. bassiana (SM3). The leaf dip method was adopted for pathogenicity bioassay. Three conidial concentrations and control were used to determine the virulence of the fungus against the aphid. The spores were adjusted into three concentrations $\left(1 \times 10^{8}, 1 \times 10^{7}\right.$, and $1 \times 10^{6}$ conidia $\left.\mathrm{mL}^{-1}\right)$, and the control had only $0.05 \%$ Tween 80 and sterile water. For each fungal treatment, a lettuce leaf section (with a diameter of $50 \mathrm{~mm}$ ) was cut and immersed into $5 \mathrm{~mL}$ conidia suspension for $10 \mathrm{~s}$. While for the control treatment, the leaf section (diameter of $50 \mathrm{~mm}$ ) was immersed into sterile water with $0.05 \%$ Tween 80 . Each treated leaf section was then placed on a Whatman No.1 sterile filter paper for $15 \mathrm{~min}$ to remove excessive conidia suspension [74]. Each treated leaf section was transferred into a Petri dish $(90 \mathrm{~mm}$ diameter, $15 \mathrm{~mm}$ depth) lined with moistened Whatman No.1 sterile filter(.Sigma-Aldrich PTY. LTD., Johannesburg, South Africa) After that, ten adult apterous aphids were transferred onto each leaf section using a camel hairbrush and under an optical microscope. Each treatment had six replicates, and each replicate had ten apterous adult aphids. The petri dishes were sealed with parafilm and incubated in the growing chamber at $25^{\circ} \mathrm{C}$ and a photoperiod of 12:12 (L:D) $h$ for seven days. The mortality was observed after five days. Insects were considered dead if they remained unresponsive after probing with camel hairbrush. Aphids that died were sterilized by dipping them into $70 \%$ ethanol for $10 \mathrm{~s}$ and rinsed with sterile distilled water for $1 \mathrm{~min}$. The cadavers were moved to Petri dishes lined with damp filter paper and were incubated at $25^{\circ} \mathrm{C}$ in the dark, with $90 \%$ relative humidity to promote fungal growth and sporulation. Mycelial outgrowth from on the insect cadaver was an indication that the insect died from the fungus.

\subsection{Greenhouse Study}

This experiment took place at CPUT in the Department of Horticultural Sciences, Bellville Campus, South Africa. Greenhouse's mean temperature was $27 \pm 3{ }^{\circ} \mathrm{C}, 70 \% \pm 3 \%$ relative humidity, and the average light intensity was 31.77 kilo lux. Two weeks old lettuce seedlings were transferred into $15 \mathrm{~cm}$ pots containing a substrate mix of $25 \%$ silica sand, $25 \%$ coco peat, $25 \%$ perlite, and $25 \%$ vermiculite. One hundred plants were planted into a 
$15 \mathrm{~cm}$ pot, separately. This experiment had four treatments, which were based on varied conidial concentrations, 0 conidia $\mathrm{mL}^{-1}, 1 \times 10^{6}$ conidia $\mathrm{mL}^{-1}, 1 \times 10^{7}$ conidia $\mathrm{mL}^{-1}$, and $1 \times 10^{8}$ conidia $\mathrm{mL}^{-1}$. Each treatment had twenty-five replicates $(n=100)$. Plants in the fungus treatment were drenched with $100 \mathrm{~mL}$ conidial suspension, while control plants were drenched with $100 \mathrm{~mL}$ sterile distilled water (0.05\% Tween 20). Plants were fed using recommended hydroponics Nutrifeed fertilizer (Starke Ayres Pty. Ltd., Cape Town, South Africa) comprising the following ingredients: $\mathrm{N}\left(65 \mathrm{mg} \mathrm{kg}^{-1}\right), \mathrm{P}\left(27 \mathrm{mg} \mathrm{kg}^{-1}\right), \mathrm{K}$ $\left(130 \mathrm{mg} \mathrm{kg}^{-1}\right), \mathrm{Ca}\left(70 \mathrm{mg} \mathrm{kg}^{-1}\right), \mathrm{Cu}\left(20 \mathrm{mg} \mathrm{kg}^{-1}\right), \mathrm{Mo}\left(10 \mathrm{mg} \mathrm{kg}^{-1}\right), \mathrm{Fe}\left(1500 \mathrm{mg} \mathrm{kg}^{-1}\right), \mathrm{Mg}$ (22 mg kg $\left.{ }^{-1}\right), \mathrm{S}\left(75 \mathrm{mg} \mathrm{kg}^{-1}\right), \mathrm{B}\left(240 \mathrm{mg} \mathrm{kg}^{-1}\right), \mathrm{Mn}\left(240 \mathrm{mg} \mathrm{kg}^{-1}\right)$, and $\mathrm{Zn}\left(240 \mathrm{mg} \mathrm{kg}^{-1}\right)$. The fertilizer was mixed with sterile distilled water at a concentration of $10 \mathrm{~g} / 5000 \mathrm{~mL}$, and $200 \mathrm{~mL}$ was added to each plant once a week. Each plant was watered with distilled water twice a week. The data were collected, plant height was measured from the soil surface to the top of the highest leaf, and crown size was measured (widest horizontal width between the leaves). After 21 days post-treatment, fresh leaves were pick-off plants and taken to the laboratory to assess fungal colonization. Twenty-five plants from each of the four treatments $(n=100)$ were screened for fungal colonization. Leaf sections were surfaced sterilized in the following sequence: $0.5 \%$ of sodium hypochlorite for two minutes, $70 \%$ ethanol for two minutes, and then rinsed with sterile distilled water for $1 \mathrm{~min}$. The sterilized leaf sections were placed on a selective solid agar plates made up of potatoes dextrose agar (PDA) half strength of $19.5 \mathrm{~g} / 1000 \mathrm{~mL}$ of sterile water containing $0.04 \mathrm{~g}$ streptomycin and $0.02 \mathrm{~g}$ ampicillin sodium salt and were incubated at $25 \pm 2{ }^{\circ} \mathrm{C}$. After six weeks post-inoculation, plants were uprooted from the pots, and roots length $\left(\mathrm{cm} \mathrm{plant}^{-1}\right)$ and fresh weight $\left(\mathrm{g} \mathrm{plant}^{-1}\right.$ ) of plants and roots were measured. Roots were separated from the aerial parts. Sub-samples of lettuce were oven-dried at $35^{\circ} \mathrm{C}$ for $168 \mathrm{~h}$, after which the dried plants were weighed $\left(\mathrm{g} \mathrm{plant}^{-1}\right)$ of roots and plants. The experiment was repeated twice.

\subsection{Antioxidants \\ 4.6.1. Sample Material}

At the end of the greenhouse experiment, plants were randomly selected based on fungal colonization. Plants were oven-dried at $35^{\circ} \mathrm{C}$ for $168 \mathrm{~h}$. The dried plant materials were ground, and the powered material transferred into plastic bags. Three samples representing three replicates were weighed for each treatment $(n=12)$, and $0.1 \mathrm{~g}$ of powdered plant material was transferred into centrifuge tubes. The samples were extracted with $25 \mathrm{~mL}$ of $60 \%$ ethanol and placed inside the incubator for $24 \mathrm{~h}$.

\subsubsection{Ferric Reducing Antioxidant Power (FRAP)}

The ferric reducing antioxidant power assay is similar to the procedure described by Benzie and Strain [75]. This assay is based on the reduction of ferric-tripyridyltriazine complex to its ferrous in the presence of antioxidants. The following reagents were used: $2.5 \mathrm{~mL}$ of a $10 \mathrm{mmol} / \mathrm{L}$ TPTZ (2,4,6- tripyridyl-s-triazine, Sigma-Aldrich, Johannesburg, South Africa) solution in $40 \mathrm{mmol} / \mathrm{L} \mathrm{HCl}$ plus $2.5 \mathrm{~mL}$ of $20 \mathrm{mmol} / \mathrm{L} \mathrm{FeCl}_{3}$ and $25 \mathrm{~mL}$ of $0.3 \mathrm{~mol} / \mathrm{L}$ acetate buffer and maintained at $\mathrm{pH} 3.6$ was prepared freshly and warmed at $37^{\circ} \mathrm{C}$. Aliquots of $40 \mu \mathrm{L}$ of the sample supernatant were mixed with $0.2 \mathrm{~mL}$ distilled water and $1.8 \mathrm{~mL}$ FRAP reagent. After incubation at $37^{\circ} \mathrm{C}$ for $10 \mathrm{~min}$, we employed spectrophotometric method to determine the absorbance of the reaction mixture at $593 \mathrm{~nm}$. The standard solution was $1 \mathrm{mmol} / \mathrm{L}_{\text {of }} \mathrm{FeSO}_{4}$, and the final result was expressed as the concentration of antioxidants having a ferric reducing ability equivalent to $1 \mathrm{mmol} / \mathrm{L} \mathrm{FeSO}_{4}$.

\subsubsection{Trolox Equivalent Antioxidant Capacity (TEAC)}

The scavenging ability of the antioxidants in lettuce was measured using the TEAC method described by Miller et al. [76]. The TEAC value is based on antioxidant's ability to scavenge the blue-green colored 2,2'-azino-bis-(3-ethylbenzthiazoline-6-sulphonic acid) 
radical $\left(\mathrm{ABTS}^{\bullet+}\right)$ radical cation relative to the $\mathrm{ABTS}^{\bullet+}$ radical cation scavenging ability of the water-soluble vitamin $\mathrm{E}$ analogue.

\subsection{Tissue Nutrient Content Analysis}

After six week-post-inoculation, 12 plants that showed fungal colonization, three from each treatment, were used for the analysis of macronutrients and micronutrients at a commercial laboratory, Bemlab (Pty) Ltd (Strand, Cape Town, South Africa). Before the analyses, the lettuce leaves were washed with teepol solution, followed by rinsing with sterile distilled water, and then drying at $65{ }^{\circ} \mathrm{C}$ overnight in an oven. The dried leaves were milled and ashed at $480{ }^{\circ} \mathrm{C}$, shaken up in a $50: 50 \mathrm{HCl}(50 \%)$ solution for extraction through filter paper [77]. The phosphorus $(\mathrm{P})$, potassium $(\mathrm{K})$, calcium $(\mathrm{Ca})$, magnesium $(\mathrm{Mg})$, Sodium $(\mathrm{Na})$, Iron $(\mathrm{Fe})$, manganese $(\mathrm{Mn})$, zinc $(\mathrm{Z})$, Boron $(\mathrm{B})$, copper $(\mathrm{Cu})$, and carbon (C) content of the extracts were analyzed as described by Miller [77]. Total nitrogen (N) content of the leaves was assessed through total combustion in a Leco $\mathrm{N}$-analyser. The unit of the macronutrients was $\mathrm{g} \mathrm{kg}^{-1}$ while micronutrients were expressed as $\mathrm{mg} \mathrm{kg}^{-1}$.

\subsection{Proximate Analysis}

\subsubsection{Sample Preparation}

Briefly, after $30 \mathrm{~min}$ of harvest, lettuce plants were frozen at $-20{ }^{\circ} \mathrm{C}$ and lyophilized. Three plants from each treatment ( $n=12$ for the four treatments) were used for the analysis. The damaged leaves were carefully removed during this preparation. Dried materials were grounded with an ultracentrifuge mill.

\subsubsection{Protein Analysis}

The method used was adopted from Chikwanha et al. [78]; nitrogen content was analyzed using the method described by Duma of macro-Nitrogen analyzer (LECO ${ }^{\circledR}$ FP528, LECO Corporation, Miami, FL, USA). Total protein content was determined by multiplying the $\mathrm{N}$ content by a factor of 6.25 . The total protein percentage was converted into $\mathrm{g} \mathrm{kg}^{-1}$.

\subsubsection{Fatty Acid Analysis}

The method was adopted from Sukhija and Palmquist [79] with minor adjustment. Fatty acids were analyzed on Agilent 7890A Gas Chromatography-Flame Ionization Detector System (Agilent Technologies, Inc., Santa Clara, CA, USA). The column used was HP88 $(100 \mathrm{~m} \times 250 \mu \mathrm{m}, 0.250 \mu \mathrm{m})$; the temperature was set at $50^{\circ} \mathrm{C}$ hold for $2 \mathrm{~min}$, increase at $5{ }^{\circ} \mathrm{C} / \mathrm{min}$ to $250{ }^{\circ} \mathrm{C}$, and hold for $15 \mathrm{~min}$. Carrier gas: Nitrogen with a flow rate set at $1.0 \mathrm{~mL} / \mathrm{min}$. Injection volume: $1 \mu \mathrm{L}$ (split; 50:1). The fatty acids were detected by evaluation of their retention times with that of internal standard. The fatty acids that were detected were expressed as $\mathrm{mg} \mathrm{kg}^{-1}$.

\subsection{Chlorophyll Content Analysis}

The chlorophyll analyses were based on the methods described by Arnon [80] and Rajalakshmi and Banu [81]. Briefly, one gram of freshly harvested plants was ground with $20-40 \mathrm{~mL}$ of acetone. It was then centrifuged for $5 \mathrm{~min}$ at 5000-10,000 rpm. After that, the supernatant was used for absorbance reading. The absorbance of the solution was read at $645 \mathrm{~nm}$ and $663 \mathrm{~nm}$ against the solvent (acetone) blank.

\section{Estimation of Chlorophyll Content}

The concentrations of total chlorophyll, chlorophyll a, and chlorophyll b were calculated using the following equations [81]

Total Chlorophyll: 20.2( $\left.\mathrm{A}_{645}\right)+8.02\left(\mathrm{~A}_{663}\right)$

Chlorophyll a: $12.7\left(\mathrm{~A}_{663}\right)-2.69\left(\mathrm{~A}_{645}\right)$

Chlorophyll b: $22.9\left(\mathrm{~A}_{645}\right)-4.68\left(\mathrm{~A}_{663}\right)$ 


\subsection{Statistical Analysis}

The data collected were plant height $(\mathrm{cm})$, crown size $(\mathrm{cm})$, roots length $(\mathrm{cm})$, plant dry weight $(\mathrm{g})$, roots dry weight $(\mathrm{g})$, plant fresh weight $(\mathrm{g})$, roots fresh weight $(\mathrm{g})$, and FRAP (Umol AAE/g), TEAC (Umol TE/g), macronutrients $\left(\mathrm{g} \mathrm{kg}^{-1}\right)$, micronutrients $\left(\mathrm{mg} \mathrm{kg}^{-1}\right)$, protein $\left(\mathrm{mg} \mathrm{kg}^{-1}\right)$, and fatty acids $\left(\mathrm{mg} \mathrm{kg}^{-1}\right)$, and chlorophyll (Mean $\pm \mathrm{SE} \mu \mathrm{g} \mathrm{g}^{-1}$ ). The growth parameters' data of the first and second experiments were pooled since no significant differences were observed when the growth results were compared. The data were then analyzed using one-way ANOVA. The data on tissue colonization were analyzed using the Fisher's exact test. Dosage mortality response was subjected to Finney's probit analysis method [82] to obtain the $\mathrm{LC}_{50}$. The analyses were performed using the statistical software TIBCO Statistica ${ }^{\circledR}$ 13.3.0 Dell Inc., California, USA. Count mortality data were arcsine square-root transformed and analyzed using one-way analysis of variance (ANOVA). The post hoc Turkey HSD was applied to separate means.

\section{Conclusions}

The B. bassiana strain used in this study was pathogenic and successfully colonized the lettuce plants inoculated with its conidia. This study further demonstrated that endophytic entomopathogen (B. bassiana) used in this study can be used to agriculturally produce biofortified lettuce-tissue micronutrients, proteins and antioxidant capacity were significantly enhanced by B. bassiana inoculation. Remarkably, we found a strong association between tissue $C$ content and antioxidant capacity of lettuce. This study revealed that tissue macronutrient and micronutrient contents can potentially mediate the influence of endophytic fungus on plant growth, antioxidant capacity and chlorophyll content. Future studies should investigate the effects of B. bassiana strain (SM 3) on plant primary and secondary metabolite contents and aphid infestations on lettuce.

Supplementary Materials: The following are available online at https:/ /www.mdpi.com/article/10 .3390 / plants10061178/s1, Figure S1. Mycelia outgrowth from leaf sections demonstrating successful colonization of tissues by the endophytic fun-gus Beauveria bassiana. Table S1. Correlation between tissue nutrients and anti-oxidant capacity (FRAP and TEAC).

Author Contributions: Conceptualization, N.M., O.O.O. and F.N.; methodology, F.N. and N.M.; validation, N.M., O.O.O. and F.N.; formal analysis, N.M. and F.N.; investigation, N.M.; resources, O.O.O. and F.N.; data curation, F.N. and N.M.; writing—original draft preparation, N.M.; writingreview and editing, F.N., N.M. and O.O.O.; visualization, N.M.; supervision, F.N. and O.O.O.; project administration, F.N. and N.M.; funding acquisition, F.N. and O.O.O. All authors have read and agreed to the published version of the manuscript.

Funding: This research was funded by CPUT, grant number URF R166. The APC was funded by CPUT.

Informed Consent Statement: Not applicable.

Data Availability Statement: Data is contained within the article.

Acknowledgments: The authors are grateful to CPUT and NRF for funding this study.

Conflicts of Interest: The authors declare no conflict of interest.

\section{References}

1. Barrière, V.; Lecompte, F.; Lescourret, F. Efficacy of pest and pathogen control, yield and quality of winter lettuce crops managed with reduced pesticide applications. Eur. J. Agron. 2015, 71, 34-43. [CrossRef]

2. Chandi, R.S.; Kataria, S.K.; Kaur, J. Arthropods as Vector of Plant Pathogens Viz-a-Viz Their Management. Int. J. Curr. Microbiol. Appl. Sci. 2018, 7, 4006-4023. [CrossRef]

3. Koch, R.L.; Hodgson, E.W.; Knodel, J.J.; Varenhorst, A.J.; Potter, B.D. Management of Insecticide-Resistant Soybean Aphids in the Upper Midwest of the United States. J. Integr. Pest Manag. 2018, 9, 1-7. [CrossRef]

4. Ricupero, M.; Desneux, N.; Zappalà, L.; Biondi, A. Target and non-target impact of systemic insecticides on a polyphagous aphid pest and its parasitoid. Chemosphere 2020, 247, 125728. [CrossRef] [PubMed] 
5. Furlan, L.; Pozzebon, A.; Duso, C.; Simon-Delso, N.; Sánchez-Bayo, F.; Marchand, P.A.; Codato, F.; van Lexmond, M.B.; Bonmatin, J.-M. An update of the Worldwide Integrated Assessment (WIA) on systemic insecticides. Part 3: Alternatives to systemic insecticides. Environ. Sci. Pollut. Res. 2021, 28, 11798-11820. [CrossRef]

6. Nair, D.N.; Padmavathy, S. Impact of Endophytic Microorganisms on Plants, Environment and Humans. Sci. World J. 2014, 2014, 1-11. [CrossRef] [PubMed]

7. Vega, F.E.; Posada, F.; Aime, M.C.; Pava-Ripoll, M.; Infante, F.; Rehner, S.A. Entomopathogenic fungal endophytes. Biol. Control. 2008, 46, 72-82. [CrossRef]

8. Shahid, A.; Rao, Q.; Bakhsh, A.; Husnain, T. Entomopathogenic fungi as biological controllers: New insights into their virulence and pathogenicity. Arch. Biol. Sci. 2012, 64, 21-42. [CrossRef]

9. Vega, F.E. The use of fungal entomopathogens as endophytes in biological control: A review. Mycologia 2018, 110, 4-30. [CrossRef]

10. Shah, S.; Shrestha, R.; Maharjan, S.; Selosse, M.A.; Pant, B. Isolation and characterization of plant growth-promoting endophytic fungi from the roots of Dendrobium moniliforme. Plants 2019, 8, 5. [CrossRef] [PubMed]

11. Chand, K.; Shah, S.; Sharma, J.; Paudel, M.R.; Pant, B. Isolation, characterization, and plant growth-promoting activities of endophytic fungi from a wild orchid Vanda cristata. Plant Signal. Behav. 2020, 15, 1744294. [CrossRef]

12. Omomowo, O.I.; Babalola, O.O. Bacterial and Fungal Endophytes: Tiny Giants with Immense Beneficial Potential for Plant Growth and Sustainable Agricultural Productivity. Microorganisms 2019, 7, 481. [CrossRef] [PubMed]

13. Tiwari, S.; Lata, C. Heavy Metal Stress, Signaling, and Tolerance Due to Plant-Associated Microbes: An Overview. Front. Plant Sci. 2018, 9, 452. [CrossRef] [PubMed]

14. Lugtenberg, B.J.; Caradus, J.R.; Johnson, L.J. Fungal endophytes for sustainable crop production. FEMS Microbiol. Ecol. 2016, 92. [CrossRef]

15. Hu, S.; Bidochka, M.J. Root colonization by endophytic insect-pathogenic fungi. J. Appl. Microbiol. 2021, 130, 570-581. [CrossRef]

16. Afandhi, A.; Widjayanti, T.; Emi, A.A.L.; Tarno, H.; Afiyanti, M.; Handoko, R.N.S. Endophytic fungi Beauveria bassiana Balsamo accelerates growth of common bean (Phaeseolus vulgaris L.). Chem. Biol. Technol. Agric. 2019, 6, 11. [CrossRef]

17. Bamisile, B.S.; Dash, C.K.; Akutse, K.S.; Keppanan, R.; Wang, L. Fungal Endophytes: Beyond Herbivore Management. Front. Microbiol. 2018, 9, 544. [CrossRef] [PubMed]

18. Saia, S.; Colla, G.; Raimondi, G.; Di Stasio, E.; Cardarelli, M.; Bonini, P.; Vitaglione, P.; De Pascale, S.; Rouphael, Y. An endophytic fungi-based biostimulant modulated lettuce yield, physiological and functional quality responses to both moderate and severe water limitation. Sci. Hortic. 2019, 256, 108595. [CrossRef]

19. Ren, A.Z.; Li, X.; Han, R.; Yin, L.J.; Wei, M.Y.; Gao, Y.B. Benefits of a symbiotic association with endophytic fungi are subject to water and nutrient availability in Achnatherum sibiricum. Plant Soil 2011, 346, 363-373. [CrossRef]

20. White, J.F.; Torres, M.S. Is plant endophyte-mediated defensive mutualism the result of oxidative stress protection? Physiol. Plant. 2010, 138, 440-446. [CrossRef]

21. Vinale, F.; Nicoletti, R.; Lacatena, F.; Marra, R.; Sacco, A.; Lombardi, N.; D’Errico, G.; Digilio, M.C.; Lorito, M.; Woo, S.L. Secondary metabolites from the endophytic fungus Talaromyces pinophilus. Nat. Prod. Res. 2017, 31, 1778-1785. [CrossRef] [PubMed]

22. Pan, F.; Su, T.-J.; Cai, S.-M.; Wu, W. Fungal endophyte-derived Fritillaria unibracteata var. wabuensis: diversity, antioxidant capacities in vitro and relations to phenolic, flavonoid or saponin compounds. Sci. Rep. 2017, 7, srep42008. [CrossRef] [PubMed]

23. Eotieno, N.; Lally, R.D.; Ekiwanuka, S.; Elloyd, A.; Eryan, D.; Germaine, K.J.; Dowling, D.N. Plant growth promotion induced by phosphate solubilizing endophytic Pseudomonas isolates. Front. Microbiol. 2015, 6, 745. [CrossRef]

24. Waqas, M.; Khan, A.L.; Kamran, M.; Hamayun, M.; Kang, S.-M.; Kim, Y.-H.; Lee, I.-J. Endophytic Fungi Produce Gibberellins and Indoleacetic Acid and Promotes Host-Plant Growth during Stress. Molecules 2012, 17, 10754-10773. [CrossRef]

25. Ismail, I.; Hamayun, M.; Sayyed, A.; Din, I.U.; Gul, H.; Hussain, A. Gibberellin and indole acetic acid production capacity of endophytic fungi isolated from Zea mays L. Int. J. Biosci. 2016, 8, 35-43. [CrossRef]

26. Jaber, L.R.; Enkerli, J. Fungal entomopathogens as endophytes: Can they promote plant growth? Biocontrol Sci. Technol. 2017, 27, 28-41. [CrossRef]

27. Lata, R.; Chowdhury, S.; Gond, S.K.; White, J.F. Induction of abiotic stress tolerance in plants by endophytic microbes. Lett. Appl. Microbiol. 2018, 66, 268-276. [CrossRef]

28. Ikram, M.; Ali, N.; Jan, G.; Jan, F.G.; Rahman, I.U.; Iqbal, A.; Hamayun, M. IAA producing fungal endophyte Penicillium roqueforti Thom., enhances stress tolerance and nutrients uptake in wheat plants grown on heavy metal contaminated soils. PLoS ONE 2018, 13, e0208150. [CrossRef]

29. Ismail, I.; Hamayun, M.; Hussain, A.; Iqbal, A.; Khan, S.A.; Lee, I.-J. Endophytic Fungus Aspergillus japonicus Mediates Host Plant Growth under Normal and Heat Stress Conditions. BioMed Res. Int. 2018, 2018, 1-11. [CrossRef]

30. Branine, M.; Bazzicalupo, A.; Branco, S. Biology and applications of endophytic insect-pathogenic fungi. PLoS Pathog. 2019, 15, e1007831. [CrossRef]

31. Rajab, L.; Ahmad, M.; Gazal, I. Endophytic establishment of the fungal entomopathogen, Beauveria bassiana (Bals.) Vuil., in cucumber plants. Egypt. J. Biol. Pest Control. 2020, 30, 1-7. [CrossRef]

32. Vega, F.E.; Goettel, M.S.; Blackwell, M.; Chandler, D.; Jackson, M.A.; Keller, S.; Koike, M.; Maniania, N.K.; Monzón, A.; Ownley, B.H.; et al. Fungal entomopathogens: New insights on their ecology. Fungal Ecol. 2009, 2, 149-159. [CrossRef]

33. Nishi, O.; Sushida, H.; Higashi, Y.; Iida, Y. Epiphytic and endophytic colonisation of tomato plants by the entomopathogenic fungus Beauveria bassiana strain GHA. Mycology 2021, 12, 39-47. [CrossRef] [PubMed] 
34. Heviefo, A.G.; Nyamador, S.W.; Glitho, I.A.; Tamo, M. Establishment of the Fungal Entomopathogen Beauveria bassiana as Endophyte in Cabbage Plant for Disease And Lepidopteran Larvae Pest Control. Bulletin de la Recherche Agronomique du Bénin $(B R A B)$, Numéro Spécial Développement Agricole Durable (DAD)-Décembre 2017, 1-12. Available online: https://www. researchgate.net/publication/323734527_Establishment_of_the_fungal_entomopathogen_Beauveria_bassiana_as_endophyte_ in_cabbage_plant_Brassica_oleracea_for_disease_and_lepidopteran_larvae_pest_control (accessed on 30 March 2021).

35. Ai, Z.; Wang, G.; Liang, C.; Liu, H.; Zhang, J.; Xue, S.; Liu, G. The Effects of nitrogen addition on the uptake and allocation of macro- and micronutrients in Bothriochloa ischaemum on Loess Plateau in China. Front. Plant Sci. 2017, 8, 1476. [CrossRef] [PubMed]

36. Ucar, E.; Ozyigit, Y.; Demirbas, A.; Guven, D.Y.; Turgut, K. Effect of different nitrogen doses on dry matter ratio, chlorophyll and macro/micro nutrient content in sweet herb (Stevia rebaudiana Bertoni). Commun. Soil Sci. Plant Anal. 2017, 48, 1231-1239. [CrossRef]

37. Ibrahim, M.H.; Jaafar, H.Z.; Rahmat, A.; Rahman, Z.A. Effects of Nitrogen Fertilization on Synthesis of Primary and Secondary Metabolites in Three Varieties of Kacip fatimah (Labisia, Pumila, and Blume). Int. J. Mol. Sci. 2011, 12, 5238-5254. [CrossRef]

38. Radušienė, J.; Marksa, M.; Ivanauskas, L.; Jakštas, V.; Çalişkan, Ö.; Kurt, D.; Odabaş, M.S.; Çirak, C. Effect of nitrogen on herb production, secondary metabolites and antioxidant activities of Hypericum pruinatum under nitrogen application. Ind. Crop. Prod. 2019, 139, 111519. [CrossRef]

39. Chen, Z.; Jin, Y.; Yao, X.; Chen, T.; Wei, X.; Li, C.; White, J.F.; Nan, Z. Fungal endophyte improves survival of Lolium perenne in low fertility soils by increasing root growth, metabolic activity and absorption of nutrients. Plant Soil 2020, 452, 185-206. [CrossRef]

40. Jurić, S.; Stracenski, K.S.; Król-Kilińska, Ż.; Žutić, I.; Uher, S.F.; Đermić, E.; Topolovec-Pintarić, S.; Vinceković, M. The enhancement of plant secondary metabolites content in Lactuca sativa L. by encapsulated bioactive agents. Sci. Rep. 2020, 10, 1-12. [CrossRef]

41. Yang, L.; Zou, Y.-N.; Tian, Z.-H.; Wu, Q.-S.; Kuča, K. Effects of beneficial endophytic fungal inoculants on plant growth and nutrient absorption of trifoliate orange seedlings. Sci. Hortic. 2021, 277, 109815. [CrossRef]

42. Javed, K.; Javed, H.; Mukhtar, T.; Qiu, D. Pathogenicity of some entomopathogenic fungal strains to green peach aphid, Myzus persicae Sulzer (Homoptera: Aphididae). Egypt. J. Biol. Pest Control. 2019, 29, 1-7. [CrossRef]

43. Motholo, L.; Booyse, M.; Hatting, J.; Tsilo, T.; Thekisoe, O. Pathogenicity of Beauveria bassiana (Hypocreales: Cordycipitaceae) against the Russian Wheat Aphid, Diuraphis noxia (Hemiptera: Aphididae). Afr. Ėntomol. 2020, 28, 455-461. [CrossRef]

44. Cheong, P.C.; Glare, T.R.; Rostás, M.; Haines, S.; Brookes, J.J.; Ford, S. Lack of involvement of chitinase in direct toxicity of Beauveria bassiana cultures to the aphid Myzus persicae. J. Invertebr. Pathol. 2020, 169, 107276. [CrossRef] [PubMed]

45. Fang, W.; Feng, J.; Fan, Y.; Zhang, Y.; Bidochka, M.J.; Leger, R.J.S.; Pei, Y. Expressing a fusion protein with protease and chitinase activities increases the virulence of the insect pathogen Beauveria bassiana. J. Invertebr. Pathol. 2009, 102, 155-159. [CrossRef] [PubMed]

46. Bayissa, W.; Ekesi, S.; Mohamed, S.A.; Kaaya, G.P.; Wagacha, J.M.; Hanna, R.; Maniania, N.K. Selection of fungal isolates for virulence against three aphid pest species of crucifers and okra. Anz. Schädlingskunde Pflanz. Umweltschutz 2017, 90, 355-368. [CrossRef]

47. Jaber, L.R.; Ownley, B.H. Can we use entomopathogenic fungi as endophytes for dual biological control of insect pests and plant pathogens? Biol. Control. 2018, 116, 36-45. [CrossRef]

48. Moloinyane, S.; Nchu, F. The effects of endophytic Beauveria bassiana inoculation on infestation level of Planococcus ficus, growth and volatile constituents of potted greenhouse grapevine (Vitis vinifera L.). Toxins 2019, 11, 72. [CrossRef] [PubMed]

49. Muvea, A.M.; Meyhöfer, R.; Subramanian, S.; Poehling, H.-M.; Ekesi, S.; Maniania, N.K. Colonization of onions by endophytic fungi and their impacts on the biology of Thrips tabaci. PLoS ONE 2014, 9, e108242. [CrossRef]

50. Dash, C.K.; Bamisile, B.S.; Keppanan, R.; Qasim, M.; Lin, Y.; Islam, S.U.; Hussain, M.; Wang, L. Endophytic entomopathogenic fungi enhance the growth of Phaseolus vulgaris L. (Fabaceae) and negatively affect the development and reproduction of Tetranychus urticae Koch (Acari: Tetranychidae). Microb. Pathog. 2018, 125, 385-392. [CrossRef]

51. Gayler, S.; Grams, T.E.E.; Heller, W.; Treutter, D.; Priesack, E. A dynamical model of environmental effects on allocation to carbon-based secondary compounds in juvenile trees. Ann. Bot. 2007, 101, 1089-1098. [CrossRef]

52. Araya, T.; Noguchi, K.; Terashima, I. Effect of nitrogen nutrition on the carbohydrate repression of photosynthesis in leaves of Phaseolus vulgaris L. J. Plant Res. 2009, 123, 371-379. [CrossRef]

53. Rozpądek, P.; Wężowicz, K.; Nosek, M.; Ważny, R.; Tokarz, K.; Lembicz, M.; Miszalski, Z.; Turnau, K. The fungal endophyte Epichloë typhina improves photosynthesis efficiency of its host orchard grass (Dactylis glomerata). Planta 2015, 242, 1025-1035. [CrossRef]

54. Ainsworth, E.A.; Bush, D.R. Carbohydrate export from the leaf: a highly regulated process and target to enhance photosynthesis and productivity. Plant Physiol. 2011, 155, 64-69. [CrossRef]

55. Smith, A.M.; Stitt, M. Coordination of carbon supply and plant growth. Plant Cell Environ. 2007, 30, 1126-1149. [CrossRef]

56. Sun, M.; Liu, X. Carbon requirements of some nematophagous, entomopathogenic and mycoparasitic hyphomycetes as fungal biocontrol agents. Mycopathology 2006, 161, 295-305. [CrossRef] [PubMed]

57. White, J.F.; Kingsley, K.L.; Zhang, Q.; Verma, R.; Obi, N.; Dvinskikh, S.; Elmore, M.T.; Verma, S.K.; Gond, S.K.; Kowalski, K.P. Review: Endophytic microbes and their potential applications in crop management. Pest Manag. Sci. 2019, 75, $2558-2565$. [CrossRef] [PubMed] 
58. Safavi, S.A.; Shah, F.A.; Pakdel, A.K.; Rasoulian, G.R.; Bandani, A.R.; Butt, T.M. Effect of nutrition on growth and virulence of the entomopathogenic fungus Beauveria bassiana. FEMS Microbiol. Lett. 2007, 270, 116-123. [CrossRef] [PubMed]

59. Vergara, C.; Araujo, K.E.C.; Sperandio, M.V.L.; Santos, L.A.; Urquiaga, S.; Zilli, J. Édson Dark septate endophytic fungi increase the activity of proton pumps, efficiency of $15 \mathrm{~N}$ recovery from ammonium sulphate, $\mathrm{N}$ content, and micronutrient levels in rice plants. Braz. J. Microbiol. 2019, 50, 825-838. [CrossRef]

60. Rout, G.R.; Sahoo, S. Role of iron in plant growth and metabolism. Rev. Agric. Sci. 2015, 3, 1-24. [CrossRef]

61. Uluisik, I.; Karakaya, H.C.; Koc, A. The importance of boron in biological systems. J. Trace Elements Med. Biol. 2018, 45, 156-162. [CrossRef]

62. Ruscitti, M.; Arango, M.; Beltrano, J. Improvement of copper stress tolerance in pepper plants (Capsicum annuum L.) by inoculation with arbuscular mycorrhizal fungi. Theor. Exp. Plant Physiol. 2017, 29, 37-49. [CrossRef]

63. Schmidt, S.B.; Husted, S. The biochemical properties of manganese in plants. Plants 2019, 8, 381. [CrossRef] [PubMed]

64. Luciano, Á.J.; Irineo, T.P.; Ocampo-Velázquez, R.V.; Feregrino-Pérez, A.A.; Hernández, A.C.; Guevara-González, R.G. Inte-grating plant nutrients and elicitors for production of secondary metabolites, sustainable crop production and human health: A review. Int. J. Agric. Biol. 2017, 19, 391-402. [CrossRef]

65. Hasanuzzaman, M.; Nahar, K.; Hossain, S.; Al Mahmud, J.; Rahman, A.; Inafuku, M.; Oku, H.; Fujita, M. Coordinated actions of glyoxalase and antioxidant defense systems in conferring abiotic stress tolerance in plants. Int. J. Mol. Sci. 2017, 18, 200. [CrossRef]

66. Carrasco-Gil, S.; Hernandez-Apaolaza, L.; Lucena, J.J. Effect of several commercial seaweed extracts in the mitigation of iron chlorosis of tomato plants (Solanum lycopersicum L.). Plant Growth Regul. 2018, 86, 401-411. [CrossRef]

67. Tripathi, D.K.; Singh, S.; Gaur, S.; Singh, S.; Yadav, V.; Liu, S.; Singh, V.P.; Sharma, S.; Srivastava, P.; Prasad, S.M.; et al. Acquisition and homeostasis of iron in higher plants and their probable role in abiotic stress tolerance. Front. Environ. Sci. 2018, 5, 1-15. [CrossRef]

68. Bidart-Bouzat, M.G.; Imeh-Nathaniel, A. Global change effects on plant chemical defenses against insect herbivores. J. Integr. Plant Biol. 2008, 50, 1339-1354. [CrossRef]

69. Ray, S.; Singh, V.; Singh, S.; Sarma, B.K.; Singh, H.B. Biochemical and histochemical analyses revealing endophytic Alcaligenes faecalis mediated suppression of oxidative stress in Abelmoschus esculentus challenged with Sclerotium rolfsii. Plant Physiol. Biochem. 2016, 109, 430-441. [CrossRef]

70. Shahabivand, S.; Parvaneh, A.; Aliloo, A.A. Root endophytic fungus Piriformospora indica affected growth, cadmium partitioning and chlorophyll fluorescence of sunflower under cadmium toxicity. Ecotoxicol. Environ. Saf. 2017, 145, 496-502. [CrossRef] [PubMed]

71. Rasheed, F.; Markgren, J.; Hedenqvist, M.; Johansson, E. Modeling to understand plant protein structure-function relationshipsimplications for seed storage proteins. Molecules 2020, 25, 873. [CrossRef]

72. Idhan, A.; Nadir, M.; Kadir, M. Paddy chlorophyll concentrations in drought stress condition and endophytic fungi application. IOP Conf. Ser. Earth Environ. Sci. 2018, 156, 012040. [CrossRef]

73. Latifian, M.; Rad, B. Pathogenicity of the entomopathogenic fungi Beauveria bassiana (Balsamo) Vuillmin, Beauveria brongniartii Saccardo and Metarhizium anisopliae Metsch to adult Oryctes elegans Prell and effects on feeding and fecundity. Intl. J. Agri. Crop Sci. 2012, 4, 1026-1032.

74. Nazir, T.; Basit, A.; Hanan, A.; Majeed, M.; Qiu, D. In vitro pathogenicity of some entomopathogenic fungal strains against green peach aphid Myzus persicae (Homoptera: Aphididae). Agronomy 2018, 9, 7. [CrossRef]

75. Benzie, I.F.F.; Strain, J.J. The ferric reducing ability of plasma (FRAP) as a measure of "antioxidant power": The FRAP assay. Anal. Biochem. 1996, 239, 70-76. [CrossRef] [PubMed]

76. Miller, N.J.; Rice-Evans, C.; Davies, M.J. A new method for measuring antioxidant activity. Biochem. Soc. Trans. 1993, 21, 95S. [CrossRef]

77. Miller, R.O. High-Temperature Oxidation: Dry Ashing. In Handbook of Reference Methods for Plant Analysis; CRC Press: Boca Raton, FL, USA, 1998; pp. 53-56, Chapter 5.

78. Chikwanha, O.C.; Muchenje, V.; Nolte, J.E.; Dugan, M.E.; Mapiye, C. Grape pomace (Vitis vinifera L. cv. Pinotage) supplementation in lamb diets: Effects on growth performance, carcass and meat quality. Meat Sci. 2019, 147, 6-12. [CrossRef] [PubMed]

79. Sukhija, P.S.; Palmquist, D.L. Rapid method for determination of total fatty acid content and composition of feedstuffs and feces. J. Agric. Food Chem. 1988, 36, 1202-1206. [CrossRef]

80. Arnon, D.I. Copper enzymes in isolated chloroplasts. polyphenoloxidase in Beta vulgaris. Plant Physiol. 1949, 24, 1-15. [CrossRef]

81. Rajalakshmi, K.; Banu, N. Extraction and estimation of chlorophyll from medicinal plants. Int. J. Sci. Res. $2015,4,209-212$.

82. Finney, D.J. Probit Analysis, 2nd ed.; Cambridge University Press: Cambridge, UK, 1952; pp. 388-390. 